\title{
Meteorológiai paraméterek változásának hatása a halálos kimenetelü aortaaneurysma-rupturákra
}

\author{
Berczeli Márton dr..$^{1}$ - Szilágyi Brigitta dr. ${ }^{3}$ - Lovas Attila dr. ${ }^{3}$ \\ Pál Dániel dr. ${ }^{1}$ - Oláh Zoltán dr. ${ }^{1}$. Törő Klára dr. ${ }^{2}$ - Sótonyi Péter dr. ${ }^{1}$ \\ Semmelweis Egyetem, Általános Orvostudományi Kar, \\ ${ }^{1}$ Városmajori Szív- és Érgyógyászati Klinika, Érsebészeti Tanszék, \\ ${ }^{2}$ Igazságügyi és Biztosítás-orvostani Intézet, Budapest \\ ${ }^{3}$ Budapesti Műszaki és Gazdaságtudományi Egyetem, Matematika Intézet, Budapest
}

\begin{abstract}
Bevezetés: Számos közlemény vizsgálta már az időjárási paraméterek változásának cardiovascularis kórképekre gyakorolt hatását. Ezek bizonyították az aortaaneurysma-ruptura előfordulásának és az idojjárás változásának kapcsolatát is. Nincsenek azonban ismereteink a függés mértékéről, arról, hogy mennyire számottevő tényező́k az egyes időjárási paraméterek ezen halálokok esetén.

Célkitüzés: Kutatásunk célja, hogy a halálos kimenetelú aortakatasztrófa nyomás- és hőmérsékletváltozástól való függésének mértékét feltárjuk, a kapcsolat intenzitását egy új módszerrel meghatározzuk.

Módszer: A korábban a tüdőembóliás halálozás és az idójárás összefüggésének tanulmányozására fejlesztett programunkat futtattuk olyan aortaaneurysmás haláleseteket tartalmazó adatsoron, amelyben az említett kórkép miatt bekövetkezett aortaruptura vezetett a páciensek halálához. A 2005. január 1. és 2014. január 1. közötti időszak eseteit tekintettük át a Semmelweis Egyetem kórbonctani adatbázisában. 152 aneurysmás eseményt vizsgáltunk a halál napján és az azt megelőző napon mért nyomás- és hőmérséklet-változás függvényében.

Eredmények és köpetkeztetés: Az említett időtartamban a halálos kimenetelú aortakatasztrófa elófordulásának gyakorisága a vizsgált csoportban kismértékủ függést mutatott a két vizsgált paramétertől. Az aortaaneurysma-rupturákkal összefüggésben a légnyomásváltozás szerepét jelentősebbnek találtuk a napi középhőmérséklet szerepéhez képest. A légnyomás növekedésével emelkedett az aneurysma rupturájával összefüggő halálesetek gyakorisága. Az eredmények ismeretében úgy véljük, hogy matematikai modellünk jó kiindulópont lehet populációs szintủ és prospektív vizsgálatokhoz egyaránt.

Orv Hetil. 2018; 159(37): 1501-1505.
\end{abstract}

Kulcsszavak: akut aortakatasztrófa, aortaaneurysma-ruptura, biometeorológia, légnyomás

\section{The effect of alternating meteorological parameters on fatally ruptured aortic aneurysms (autopsy-based data)}

Introduction: There are several statements about the connection between cardiovascular diseases and climate change. On behalf of our observation-based knowledge we hypothesized a relationship between the occurence of aortic aneurysm (AA) rupture and weather changes.

Aim: The purpose of our study was to explore the relationship between fatal aortic catastrophe and changes in atmospheric pressure and temperature. By using a new method we could even measure the intensity of the connection. Method: We have developed a software earlier to examine the link between pulmonary embolism mortality and the weather on data sets comprised of aortic aneurysm cases, where the medical condition had led to the fatal rupture of the aorta. For the events mentioned earlier we used the autopsy database of Semmelweis University between January 1, 2005 and January 1, 2014. Altogether we examined 152 aneurysm-related aortic catastrophes. We reported the exact day of the incident and the weather conditions on that day and the day before.

Results and conclusion: We have defined that the occurrence rate of fatal aortic catastrophe showed a slight dependence on the two examined parameters within our groups. We have found the connection related to ruptured aortic aneurysm and changes in atmospheric pressure more significant than their connection with mean daily temperatures. 
With the increase in atmospheric pressure, the rate of AA mortality also increased. In the knowledge of our results we believe that the mathematical model we used can be an effective starting point for population-based and prospective studies.

Keywords: acute aortic catastrophe, ruptured aortic aneurysm, biometeorology, atmospheric pressure

Berczeli M, Szilágyi B, Lovas A, Pál D, Oláh Z, Törő K, Sótonyi P. [The effect of alternating meteorological parameters on fatally ruptured aortic aneurysms (autopsy-based data)]. Orv Hetil. 2018; 159(37): 1501-1505.

(Beérkezett: 2018. április 7.; elfogadva: 2018. április 26.)

\section{Rövidítések}

$\mathrm{AA}=$ aortaaneurysma; $\mathrm{AAK}=$ akut aortakatasztrófa; ECMWF $=$ (European Centre for Medium-Range Weather Forecast) Középtávú Időjárás-előrejelzések Európai Központja; rAA = rupturált aortaaneurysma

A Lancet Bizottság 2009-es jelentése szerint századunk legnagyobb egészségügyi kihívása a klímaváltozás [1]. Ennek ökoszisztémára gyakorolt hatása mellett nagyobb figyelem fordul az orvosmeteorológiai kutatások felé is. A különböző meteorológiai paraméterek változásának okán bekövetkező változások kutatása kiemelkedő jelentőségüvé vált.

Az időjárási paraméterek élettani hatásainak elemzése rendkívül összetett feladat, mivel az egyes tényezők ritkán jelentkeznek egymástól függetlenül, hatásukat általában együttesen fejtik ki. A szélsőséges hőmérséklet-változás okozta környezeti stressz, valamint az ezekhez társuló légnyomásváltozások befolyásolják a mortalitási adatokat $[2,3]$. Az aortát érintő akut elváltozások közvetlen életveszéllyel fenyegető katasztrófák, melyek hátterében állhat aortadissectio, aneurysmaruptura, intramuralis haematoma, penetráló aortafekély, esetleg egyéb elváltozás [4]. Ezen rendkívül magas halálozással járó jelenségek mögött a leggyakrabban akut aortadissectio vagy aortaaneurysma (AA)-ruptura áll [4]. A rupturált aortaaneurysma (rAA) által okozott akut aortakatasztrófa (AAK) mortalitása meghaladja a $80 \%$-ot [5]. A betegség kialakulásában rizikófaktornak számít a genetikai prediszpozíció, a kötőszöveti betegségek, a férfinem, a 65 év feletti életkor és a dohányzás is [6-10]. Ezen ismeretek alapján javasolt a rizikócsoportok felállítása és szürése. Így csökkenthető lenne az évenkénti összhalálozás, illetve több, idejében felfedezett beteg részesülhetne elektív ellátásban. A jelenleg múködő ellátórendszernek meg kell birkóznia az éghajlatváltozás következményeivel. A szív- és érbeteg egyének orvosmeteorológiai szempontból emelkedett rizikójú csoportba sorolhatók, bizonyos időjárási mintázatok esetén ebben a populációban a betegségekkel járó tünetek előfordulási gyakorisága megnő [11-14]. Számos cikk született, amely az időjárás aneurysmákra gyakorolt hatását vizsgálta [12, 15-18].
Ezek mindegyike a kapcsolat meglétének kimutatására törekszik az adott kórkép és az időjárási paraméter vagy annak változása között. Sokkal reálisabb képet kapunk azonban akkor, ha a függés mértékét is számszerúsíteni tudjuk, ezért használtuk a kevert Poisson-folyamatokat, melyeket korábban a halálos kimenetelű tüdőembóliáknak a biometeorológiai paraméterekkel való összefüggésével kapcsolatban írt munkánkban alkalmaztunk [14].

A Cox-folyamatokat a pénzügyi matematikában előszeretettel használják olyan pénzpiaci termékek ármodelljeiben, amelyekben a hitelkockázat döntő szerepet játszik [19]. A számítógépek kapacitásának gyors ütemú fejlődése lehetőséget adott az összetett, számításigényes statisztikai módszerek alkalmazására is.

\section{Módszer}

\section{Az igazságügyi orvostani adatok}

Kutatásunkban a Semmelweis Egyetem Igazságügyi és Biztosítás-orvostani Intézetének 9 évi boncolási anyagát tekintettük át. A nevezett intézetben 2005. január l. és 2014. január 1. közötti esetekre koncentráltunk, ezen időszak alatt összesen 23594 boncolást végeztek. Az áttekintett boncolási jegyzőkönyvek alapján a beválasztási kritériumok a következők voltak: 1. a vizsgált személyek halálát kizárólag igazolt aortaaneurysma-ruptura okozta, 2. nagy pontossággal lehetett tudni az aortaruptura időpontját és körülményeit.

\section{A meteorológiai adatok}

A haláleset napján fennálló napi középhőmérsékletet és a halálesetet megelőző napon mért értékekhez képest vett légnyomásváltozást tekintettük alapul. A modell alkalmazhatósága szempontjából fontos volt számunkra a vizsgált meteorológiai paraméterek normáleloszlása. A meteorológiai adatok kiválasztásakor a halál bekövetkeztének időpontja mellett figyelembe vettük annak földrajzi helyét is. A munka során használt időjárási adatok a European Centre for Medium-Range Weather Forecast (ECMWF) adatbázisából származnak. 


\section{Eredmények}

Összesen 152, igazoltan rupturált aortaaneurysma miatti halálesettel foglalkoztunk az adott időintervallumban, közöttük 94 volt férfi és 58 nő. Átlagéletkoruk 72,08 év volt.

Az 1. és 2. táblázatunkban mutatjuk be a vizsgált időszakban a rAA-k havi és évszakonkénti eloszlását nemek szerinti bontásban.

Kórképeinknél sikerült megadnunk, hogy az „átlagos” időjárási viszonyokhoz képest az adott időjárási körülmények milyen mértékben növelik a regisztrált halálesetek számát. Ez azonban nem jelenti azt, hogy a modellből arra is választ kapnánk, milyen élettani paraméterek vagy egyéb, az időjárási körülmények hatására bekövetkező kóros állapotok vezetnek végül a rupturához. Vizsgálataink azt mutatták, hogy bizonyos légnyomásváltozás idején gyakoribb volt az aortaruptura. A hosszú matematikai levezetéseket mellőzve elmondhatjuk, hogy sikerült zárt formulát adnunk a függés mértékére. A szintvonalas 1 .ábrán szemléltetjük az adott időjárási körülmények között bekövetkező haláleseteket. Az egyes évszakokat különböző jellel láttuk el. A szintvonalakon feltüntetett számértékek azt jelentik, hogy adott időjárási paraméterek mellett a regisztrált halálesetek előfordulásának gyakorisága várhatóan hány \%-kal nagyobb vagy kisebb, mint a leggyakoribb, azaz átlagos időjárási körülmények mellett.

1. táblázat | A ruptura előfordulása havonként, nemek szerinti bontásban (2005-2014)

\begin{tabular}{lccc}
\hline & Férfi (fö) & Nő (fö) & Összes (fö) \\
\hline Január & 9 & 5 & 14 \\
Február & 9 & 2 & 11 \\
Március & 5 & 6 & 11 \\
Április & 12 & 9 & 21 \\
Május & 7 & 7 & 14 \\
Június & 8 & 1 & 9 \\
Július & 4 & 7 & 11 \\
Augusztus & 9 & 4 & 13 \\
Szeptember & 9 & 5 & 14 \\
Október & 5 & 4 & 9 \\
November & 7 & 4 & 11 \\
December & 10 & 4 & 14 \\
\hline
\end{tabular}

2. táblázat |A ruptura előfordulása évszakonként, nemek szerinti bontásban (2005-2014)

\begin{tabular}{lccc}
\hline & Férfi (fö) & Nő (fö) & Összes (fö) \\
\hline Tél & 28 & 11 & 39 \\
Tavasz & 24 & 22 & 46 \\
Nyár & 21 & 12 & 33 \\
Ősz & 21 & 13 & 34 \\
\hline
\end{tabular}

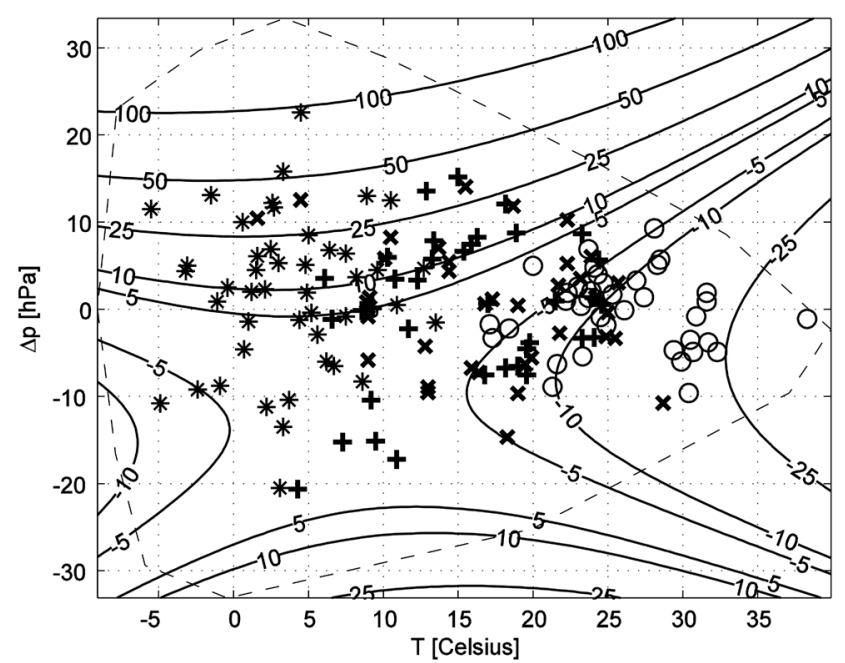

1. ábra $\quad$ A halálos rAA előfordulása a nyomásváltozás és a külső hőmérséklet függvényében

rAA = rupturált aortaaneurysma

Az 1. ábrán az rAA okozta haláleset bekövetkezésének és a hőmérséklet, illetve a légnyomás változásának eredményeit szemléltetjük.

Az ábrán feltüntettük az összes, megfigyelt időszakban előforduló időjárási körülmény konvex burkát. Érdemes az így kijelölt tartományt a modell érvényességi határának tekinteni.

$\mathrm{Az}$ aortaaneurysma-ruptura és az éghajlati paraméterek összefüggését bemutató ábráról leolvasható, hogy ha alacsony átlaghőmérséklethez légnyomás-emelkedés társul, akkor jelentősen nő a halálesetek előfordulásának gyakorisága. A $0-10{ }^{\circ} \mathrm{C}$-os tartományban, 5 hPa légnyomás-növekedéshez több mint 10\%-os esélynövekedés tartozik. Magas átlaghőmérséklet esetén a légnyomásváltozás hatása a fatális AA-rupturák előfordulására csekélyebb volt. Például $0{ }^{\circ} \mathrm{C}$ napi középhőmérséklet esetén, ha a légnyomásváltozás $10 \mathrm{hPa}$, az esélynövekedés több mint $25 \%$-os. Ugyanakkor $25^{\circ} \mathrm{C}$ napi középhőmérsékleten ugyanekkora nyomásváltozás $5 \%$ körüli esélyváltozást eredményez. A jelek nagyobb sürüsége az események gyakoriságára utal.

\section{Megbeszélés}

A különböző időjárási paraméterek és az akut aortaszindrómák kapcsolatát korábban már többen is vizsgálták [12, 15-18, 20, 21]. A korai vizsgálatok elsősorban az évszakonként, illetve havonként változó mortalitást tanulmányozták $[15,17,20]$. Bown és mtsai a légköri nyomásváltozással kapcsolatos összefüggéseket keresték [16], Majd és munkatársaiboz [18], illetve Urbanek és munkatársaiboz [22] hasonlóan a légnyomáson kívül hőmérsékleti adatokat is figyelembe vettek.

Az általunk vizsgált majdnem egy évtized az időintervallum hosszát tekintve is kiemelkedőnek mondható. 
A hosszabb időtartam jobb lehetőséget ad a tendenciák megfigyelésére. Mi 152 rAA-eset vizsgálatát végeztük el. Ez, összehasonlítva a korábban említett munkákkal, az aneurysmák számát tekintve nem számít kiemelkedő értéknek. Ballaro és mtsai lényegesen nagyobb esetszámot tekintettek át, mint mi, viszont munkájukban nyomásváltozást nem vizsgáltak, az évszakonkénti incidenciákat nézték [15]. Bown és mtsai 580 rupturált aortaaneurysmával foglalkoztak [16]. Upshur és mtsai 2373 akut aortaszindrómás esetról írnak [20], az aneurysmás és dissectiós eseteket nem tárgyalták külön. Az időjárási paraméterektől való függés mértékének kiszámításával egyetlen tanulmány sem foglalkozott eddig. Módszereinket tekintve vizsgálatunk nagy előnye, hogy minden eset részletes kórbonctani dokumentációja rendelkezésünkre állt, ezáltal a legtöbb esetben mind az aorta elváltozásairól, mind a halálesetek körülményeiről részletes és megbízható információkkal rendelkeztünk.

Az általunk alkalmazott matematikai modell alkalmas volt arra, hogy segítségével a vizsgált időjárási paraméterektől való függés mértékét megadhassuk. Saját adatainkat tekintve elmondható, hogy a tavaszi hónapokban fordult elő a legtöbb rAA-s eset, míg az aneurysmarupturával foglalkozó cikkekben inkább a téli hónapokban regisztráltak eseteket $[15,17]$. Eredményeinkben vannak látszólagos ellentmondások a korábban idézett irodalmi adatokkal. Ha azonban figyelembe vesszük azt a tényt, hogy az aortakatasztrófák elsősorban a nyomás változására reagálnak érzékenyebben, ez megmagyarázza, miért fordultak elő gyakrabban AA-halálesetek a tavaszi és téli hónapokban. A hőmérséklettől való kisebb mértékű függés magyarázza az eltérő évszakokat.

A modellünk segítségével elvégzett számítások azt mutatják, hogy az aneurysmás kórkép esetén a hőmérséklet változásánál jelentősebb szerepe volt a légnyomás változásának. Vizsgálatunk során megállapítottuk, hogy a légnyomás-emelkedéssel nőtt a halálos kimenetelü aortarupturák előfordulása. Jól ismert, hogy hidegfront esetén egy hidegebb légtömeg érkezik a jelen lévő melegebbhez, és mivel az érkező légtömeg súlya nagyobb, a meleg légtömeg alá gyưri magát. A hidegfront következtében a légnyomás először csökken, aztán pedig - gyakran igen gyorsan - emelkedik. Mindez csapadékkal és a hőmérséklet lehúlésével jár együtt. Az általunk alkalmazott matematikai modell a légnyomás gyors emelkedését „érzékelte”, és mellette a hidegfrontból visszamaradt alacsony napi középhőmérsékletet. Mindezek fényében azt mondhatjuk, hogy a hidegfront növelte az AA talaján kialakult fatális aortaaneurysma-rupturás esetek előfordulását. Ezzel szemben Bown és mtsai fordított arányosságot írtak le [16], míg Majd és mtsai nem tapasztaltak egyértelmú összefüggést a légnyomás és a rupturált esetek előfordulása között [18]. Véleményünk szerint az eredmények közötti különbségeket az eltérő vizsgálati módszerek és az egyes országok közötti lokális éghajlati különbségek is adhatták.
A nagyon hideg (fagypont alatti) átlaghőmérséklet esetén a halálozás valószínúségének kismértékü csökkenése azzal magyarázható, hogy az emberek meleg helyen töltik el a nap legnagyobb részét, tehát nincsenek igazából kitéve ezeknek az időjárási körülményeknek.

A modell által kapott adatok értelmében, amikor az átlaghőmérséklet $25^{\circ} \mathrm{C}$-nál magasabb, akkor a ruptura előfordulása lényegesen alacsonyabb, és a légnyomásváltozástól nem függ számottevően. Megfigyelhető ugyan, hogy sok esemény esik a meleg, légnyomásváltozástól mentes napokra, és ennek ellenére a modell kis esélyt jósol ezeken a napokon. Ez azért van, mert ilyen napból sok van az évben, és a sok ilyen napon kisebb esély mellett is több esemény történik, mint nagyobb esélyértékkel rendelkező, de ritkábban előforduló időjárási körülmények mellett.

Ahogy már említettük, a korábbi kutatások csak a kórképek és az időjárási paraméterek közötti kapcsolat meglétét igyekeztek kimutatni. Mi azzal a feltevéssel éltünk, hogy van kapcsolat, és ennek a kapcsolatnak az erősségét igyekeztünk feltérképezni. Fontos ismét hangsúlyozni, hogy modellünk kiszüri az egyes időjárási körülmények gyakoriságából fakadó torzítást, ami a fentebb említett dolgozatokban alkalmazott vizsgálati módszerek esetén nem történt meg.

A modell kizárólag az időjárási paraméterek megváltozásának hatására bekövetkezett rupturáról ad tájékoztatást. Ismert, hogy van kapcsolat a meteorológiai paraméterek megváltozása és a vizsgált két kórkép között, s ennek a függésnek a mértéke számszerüsíthető a modell alkalmazásával. Ez nem jelenti azonban azt, hogy más tényezők ne lennének hatással a rupturára. Ezen hatások mértékét megmondani nem áll módunkban, noha az időjárásnál jelentősebb tényező is szerepelhet közöttük.

\section{Következtetések}

9 év igazságügyi beteganyagának átvizsgálása után arra következtetünk, hogy a légnyomásváltozás a napi középhőmérséklethez képest jelentősebb hatással bír az AA-val járó fatális aortaruptura előfordulásának gyakoriságára. A légnyomás hirtelen növekedésével együtt nőhet az AA okozta halálozás valószínúsége.

A Cox-folyamat segítségével már meglévő kapcsolatok ismeretében képesek vagyunk a függés mértékét, ezáltal az esemény bekövetkezésének valószínűségét feltárni. A modell lehetőséget ad két vagy több paramétertól való együttes függés mértékének kiszámítására is. Az sem szükséges, hogy a paraméterek meteorológiai eredettel bírjanak, egyetlen kívánalom, hogy normális eloszlású valószínűségi változók legyenek. Az időjárás folyamatos változást mutat, jól leírható tendenciák mentén. Ezek egyes földrajzi régiókban vagy országok területén pontosan kimutathatók. Az egyes betegségekre vonatkozó regionális vagy országos adatbázisok elemzésével lehetőség nyílhatna bizonyos kórképek (például akut myocardialis infarctus, stroke, asthma bronchiale) inci- 
denciájában és prevalenciájában bekövetkező változások becslésére az időjárási paraméterek függvényében. Jövőbeli terveink között szerepel a módszer alkalmazása más cardio- és cerebrovascularis kórképek esetén. Ezen tényezők ismerete, úgy gondoljuk, felhasználhatóvá válhat a kórképek prevenciójában.

Anyagi támogatás: Munkánk megírása és a hozzá kapcsolódó kutatómunka anyagi támogatásban nem részesült.

Szerzői munkamegosztás: B. M.: Adatfeldolgozás, a közlemény felépítésének kigondolása, az irodalmi háttér áttekintése, az eredmények értékelése, a közlemény szövegének megfogalmazása. Sz. B.: A közlemény felépítésének kigondolása, az eredmények értékelése, a matematikai módszer kidolgozása, a közlemény szövegének megfogalmazása. L. A.: A matematikai módszer kidolgozása és alkalmazása. P. D.: Adatgyűjtés, adatfeldolgozás. O. Z., T. K.: A közlemény felépítésének kigondolása, az eredmények értékelése. S. P.: A közlemény felépítésének kigondolása, az eredmények értékelése, a közlemény szövegének megfogalmazása. A cikk végleges változatát valamennyi szerző elolvasta és jóváhagyta.

Érdekeltségek: A szerzőknek nincsenek érdekeltségeik.

\section{Irodalom}

[1] Costello A, Abbas M, Allen A, et al. Managing the health effects of climate change. Lancet and University College London Institute for Global Health Commission. Lancet 2009; 373: $1693-$ 1733

[2] Liu C, Yavar Z, Sun Q. Cardiovascular response to thermoregulatory challenges. Am J Physiol Heart Circ Physiol. 2015; 309: H1793-H1812.

[3] Wang X, Li G, Liu L, et al. Effects of extreme temperatures on cause-specific cardiovascular mortality in China. Int J Environ Res Public Health 2015; 12: 16136-16156.

[4] Carpenter SW, Kodolitsch YV, Debus ES, et al. Acute aortic syndromes: definition, prognosis and treatment options. J Cardiovasc Surg. 2014; 55(2 Suppl 1): 133-144.

[5] Reimerink JJ, van der Laan MJ, Koelemay MJ, et al. Systematic review and meta-analysis of population-based mortality from ruptured abdominal aortic aneurysm. Br J Surg. 2013; 100: $1405-1413$

[6] Akai A, Watanabe Y, Hoshina K, et al. Family history of aortic aneurysm is an independent risk factor for more rapid growth of small abdominal aortic aneurysms in Japan. J Vasc Surg. 2015; 61: $287-290$.
[7] MacSweeney ST, Powell JT, Greenhalgh RM. Pathogenesis of abdominal aortic aneurysm. Br J Surg. 1994; 81: 935-941.

[8] Powell JT, Adamson J, MacSweeney ST, et al. Genetic variants of collagen III and abdominal aortic aneurysm. Eur J Vasc Surg. 1991; 5: 145-148.

[9] Powell JT, Worrell P, MacSweeney ST, et al. Smoking as a risk factor for abdominal aortic aneurysm. Ann N Y Acad Sci. 1996; 800: $246-248$.

[10] Brady AR, Thompson SG, Fowkes FG, et al. Abdominal aortic aneurysm expansion - risk factors and time intervals for surveillance. Circulation 2004; 110: 16-21.

[11] Boussoussou N, Boussoussou M, Nemes A. Historical overview of medical meteorology - the new horizon in medical prevention. [Az orvosmeteorológia történeti áttekintése - új horizont a preventív medicina területén.] Orv Hetil. 2017; 158: 187-191. [Hungarian]

[12] Ishikawa K, Niwa M, Tanaka T. Difference of intensity and disparity in impact of climate on several vascular diseases. Heart Vessels 2012; 27: 1-9.

[13] Boussoussou N, Boussoussou M, Entz L, et al. Occurrence of acute cardiovascular diseases under different atmospheric parameters. [Akut cardiovascularis kórképek vizsgálata különböző légköri paraméterek tükrében.] Orv Hetil. 2014; 155: 1078-1082. [Hungarian]

[14] Törő K, Pongrácz R, Bartholy J, et al. Evaluation of meteorological and epidemiological characteristics of fatal pulmonary embolism. Int J Biometeorol. 2016; 60: 351-359.

[15] Ballaro A, Cortina-Borja M, Collin J. A seasonal variation in the incidence of ruptured abdominal aortic aneurysms. Eur J Vasc Endovase Surg. 1998; 15: 429-431.

[16] Bown MJ, McCarthy MJ, Bell PR, et al. Low atmospheric pressure is associated with rupture of abdominal aortic aneurysms. Eur J Vasc Endovasc Surg. 2003; 25: 68-71.

[17] Liapis C, Sechas M, Iliopoulos D, et al. Seasonal variation in the incidence of ruptured abdominal aortic aneurysm. Eur J Vasc Surg. 1992; 6: 416-418.

[18] Majd P, Ahmad W, Luebke T, et al. The atmospheric pressure and temperature seem to have no effect on the incidence of rupture of abdominal aortic aneurysm in a Mid-European Region. Ann Vasc Surg. 2017; 42: 183-188.

[19] Lando D. On Cox processes and credit risky securities. Rev Deriv Res. 1998; 2: 99-120.

[20] Upshur RE, Mamdani MM, Knight K. Are there seasonal patterns to ruptured aortic aneurysms and dissections of the aorta? Eur J Vasc Endovasc Surg. 2000; 20: 173-176.

[21] Repanos C, Chadha NK. Is there a relationship between weather conditions and aortic dissection? BMC Surg. 2005; 5: 21.

[22] Urbanek T, Juśko M, Niewiem A, et al. The influence of atmospheric pressure on aortic aneurysm rupture - is the diameter of the aneurysm important? Kardiol Pol. 2015; 73: 1327-1333.

(Berczeli Márton dr., Budapest, Városmajor u. 68., 1122 e-mail: marton.berczeli@gmail.com)

A cikk a Creative Commons Attribution-NonCommercial 4.0 International License (https://creativecommons.org/licenses/by-nc/4.0) feltételei szerint publikált Open Access közlemény, melynek szellemében a cikk nem kereskedelmi célból bármilyen médiumban szabadon felhasználható, megosztható és újraközölhetö, feltéve, hogy az eredeti szerző és a közlés helye, illetve a CC License linkje és az esetlegesen végrehajtott módositások feltüntetésre kerülnek. 